\title{
SILVICULTURAL RESULTS OF FOREST POLICIES AND PRACTICES IN MANITOBA AND SASKATCHEWAN'
}

\author{
BY V. H. PHELPS
}

Department of Resources and Development, Winnipeg, Manitoba

As is common in sparsely populated countries, the policies and practices towards the forests are closely concerned with the progress of settlement. In most cases, the term "practice" might better be termed "malpractice".

Towards the latter part of the 19th Century the province of Manitoba was created and subsequently the rate of settlement continued to rise steadily. Following the creation of the province of Saskatchewan in $1905 \mathrm{immi}$ gration increased at a tremendous rate and the population multiplied rapidly. The principal attraction to the settlers was the rich farm lands and the economy of the Prairies was on an agricultural basis. In these circumstances governmental administration regarded the forests from the viewpoint of the farmer. The great influx of settlers made proper and adequate land classification impossible and where timbered lands were demanded for agricultural purposes they were often granted even on areas which were more suited to growing wood. The traditional attitude of settlers, that forests are a hindrance, resulted in much destruction and further depletion of vast forests by fires, set either intentionally or by carelessness. As these tendencies increased, however, there were indications of a consciousness of the value of the forests developing. Evidence of this is shown by the establishment of forest reserves on suitable sites and improvements in fire protection.

During the period 1870 to 1930 the administration of natural resources in these provinces was under the jurisdiction of the Dominion Government. Numerous acts were passed that were concerned with the administration of the forests. These provided woodlots for prairie farms, designated areas as timber districts from which settlement was excluded, determined the size of timber berths and regulations for the lessee. The first step to provide for future forest production on Crown Lands was that a 10-inch minimum stump-diameter limit was established for all sawmills. At the beginning of the 20th Century the necessity for the conservation of forest resources was recognized, and the policy of employing technically trained foresters was inaugurated. The establishment of further forest reserves continued and the policy was to eventually bring these under sound forest management. Protection from fire was the primary duty of the administrative staff of the reserve but efforts were made to control timber operations to provide for reproduction and the proper disposal of logging slash. Eventually the responsibility of the Dominion Government was increased to include protection from fire of all forests, both inside and outside the reserves. During the period after the 1914-18 war, there was great

1 Paper presented at the annual meeting of the Caxadian Society of Forest Engineens at Sant Ste Marie, Ontario, October 26-28, 1950 
activity in stock-taking, rate of growth and management surveys, and eventually in 1930 the resources were transferred to the provinces.

Since the transfer of the resources the administration and forest policiees of the forests have been the responsibility of the provincial governments. Regulations have been passed and funds expended to provide improvements in fire protection; aircraft and towers are used for detection to the extent of the available funds; minimum cutting diameter limits have been increased; timber is selectively marked for removal and efforts are being made to procure natural regeneration.

This summarizes briefly the forest policies up until the past few years. A description of the effect of these practices will be principally confined to the white spruce-aspen forest type.

Most of the timbered areas in these provinces are in the forest region designated by Halliday (1) as the Boreal Forest Region. The most important sub-type is an association of white spruce and aspen, the former species being the most important commercially. It grows particularly well and is the source of most of our saw timber. Because of its value and importance silvicultural policies and practices have been concerned with its management and perpetuation.

The unwise exploitation of the forests and the frequency of forest fires due largely to the carelessness of the people have greatly reduced the merchantable stands of timber and production possibilities of the forests. The majority of those that were cut or burned in the past do not now have residual stands that are capable of producing new forests equivalent to the ones removed. The introduction of the selective system of logging white spruce was intended to provide for natural regeneration and to increase the rate of increment on the residual trees. Unfortunately, this well-intentioned plan has not proven too successful. Increased growth is often counteracted by increased windthrow and usually natural regeneration is inadequate. Disturbance in these mixedwood stands, either by logging or fire, resulted in most cases in an invasion of minor vegetation and hardwood seedlings and comparatively few coniferous seedlings. Seedlings that did become established experienced difficulty surviving due to competition. These conditions have resulted in numerous areas on which at one time grew good productive forests now only being sparsely stocked or supporting inferior species.

During the past decade more funds and personnal have become available to implement silvicultural practices aimed at conservation of the forest resources. Considerable progress has been made and is continuing. Further experimentation is required in some instances before practices can be applied on a large-scale basis but there are indications that forests recently cut or to be cut in the future are not and will not be exploited but will be managed on a sustained yield basis.

In 1947 a Royal Commission was appointed in the province of Saskatchewan to report on and inquire into matters pertaining to forest resources. Subsequent to the inquiry regulations have been enforced which require (1) Halliday, W. E. D. A Forest Claesiflcation for Canada. Dominion Foret Service Bulletin
$89-1937$. 
that all green spruce be marked for removal by qualified departmental officers; a minimum cutting diameter limit of 14 inches d.b.h. is imposed and an endeavour made to retain not less than 40 per cent of crown cover.

In order to extend operations in the mature timber the annual cut has been reduced from a maximum of $160,000,000$ f.b.m., reached during the war, to an allowable cut of $40,000,000$ f.b.m. This means that instead of cutting all the mature forests in a period of six to seven years, it will now require twenty years. Each district has a quota within which it must operate.

Two large areas, containing approximately $150,000,000$ f.b.m. of white spruce, are being managed according to a proper plan. The policy followed is usually to allow a period of fifteen years to remove a proportion of the mature and over-mature timber within the area of the plan and then to cut on a sustained yield basis. The plans at present deal chiefly with saw timber but are capable of being altered at any time for any change in markets.

Except for timber originating on timber berths, the manufacture and sale of all spruce saw timber, pulpwood, railway ties, boxwood and telephone and power line poles is carried on in the province by a Crown corporation, the Saskatchewan Timber Board. The Department of Natural Resources designates the timber to be removed and the conditions of its removal and disposes of it to the Timber Board.

All lands north of the agricultural belt have now been placed within one Northern Provincial Forest and cover the entire northern half of the province. Integrated operations are being encouraged and are becoming more numerous and on these tops are taken out to eight inches and the balance of the tree turned into pulpwood.

In the province of Manitoba certain of the forest reserves are being intensively managed under a working plan. In such cases trees are marked before removal. Although the cutting diameter limit is flexible, dependent upon local conditions, it is usually 12 inches at stump height. Except in isolated areas, white spruce is cut either by the shelterwood or selective system. Jack pine is usually clear-cut after natural regeneration is established, although in a few instances logging is on a selective basis. Hardwoods are clear-cut and reproduced from suckers. Efforts are being made, with some success, to pronote the use of poplar and balsam fir species, which were formerly considered inferior.

Integrated operations are being encouraged and progress has been made in cutting jack pine where transmission line poles and fuelwood are produced from the same operation. During the past year an Order-inCouncil has been passed restricting the number of years that a settler can cut timber for use on his own farm. A period of five years after the settler is established is now considered sufficient time for him to obtain timber for his farm. It is considered that such legislation will decrease the large number of small and separate woods operations and increase the amount of timber cut as timber sales. Plans can be made for timber sales that are designed to meet local conditions and at the same time are based on sound 
forestry practices, whereas on numerous small and scattered operations, this would not always be practicable.

Experimental work is proceeding to find ways of increasing the amount of present inadequate white spruce reproduction. Investigations designed to encourage natural seeding on ground which has been scarified by different methods and tools have been tried and in some cases resulted in considerable success. Efforts are now being made to determine the chief causes of mortality of the young seedlings after establishment. As yet the results are not sufficiently conclusive to warrant large scale application of the treatments. It is hoped that further work will eventually improvise a practical silvicultural treatment that will assure establishment and survival of seedlings from natural seeding. The existence of a relationship between the amount of regeneration and the method of logging slash disposal is also being examined and is expected to reveal some valuable information. It is considered that when these problems are solved it will be possible to extend the application of silviculture in the mixedwood forests to the extent that, unless abnormal catastrophies occur, continuous productive forests will be assured.

There is less effort towards the application of silviculture for other species. The natural reproduction of black spruce and poplar following the usual clear-cutting operations is not a critical problem. Some concern is felt over the stagnated condition of many of the dense black spruce low value stands and there are investigations in progress to obtain very low operating costs by strip thinning with power equipment. It is hoped that, if stands where the monetary returns are low can be given a beneficial treatment at an even lower cost, operators will be encouraged to cut them and leave a residual stand that will be at least a normal growing productive forest instead of an area of stagnation.

The natural reproduction of jack pine is difficult on some sites and one of the problems for investigation is designed to obtain regeneration from lopping the logging slash and scattering it on the previously scarified forest floor. As yet these experiments have not yet sufficiently advanced to justify application on an extensive scale. 